\title{
Land Resource In Tanzania: Whose State, Whose Resource? ${ }^{1}$
}

\author{
Evaristo Haulle ${ }^{1}$ \\ ${ }^{1}$ Department of Geography, Mkwawa University College of Education (MUCE) of the University of Dar es Salaam, \\ Tanzania. \\ Correspondence: Evaristo Haulle, Department of Geography, Mkwawa University College of Education (MUCE) of the \\ University of Dar es Salaam, Tanzania.
}

Received: August 31, 2015

doi:10.11114/ijsss.v3i6.1102
Accepted: September 11, $2015 \quad$ Available online: September 23, 2015

URL: http://dx.doi.org/10.11114/ijsss.v3i6.1102

\begin{abstract}
This paper assesses land resource in Tanzania in relation to ownership, access and control for livelihood and development. The ownership of state and resources impacts the community stability and development. The paper employs political ecology approach to analyze the state of art in relation to land. In-depth interviews, Focus Group Discussions and Literature review were employed to establish historical trend in relation to conflicts and contradictions that exist in resource management. The paper advances that, since 1895, Tanzania has undergone a number of land reforms. Since then, principles of land tenure have not changed. This resulted to conflicts over land which occurs in different forms and scale. After independence, land was dispossessed in the name of national/or public interest to establish National Parks, agricultural projects and other projects that did not respond to internal demands. After the failure of the projects such land was not returned to the users. Moreover, Tanzania has formulated a number of laws to facilitate accumulation. These include commodification of land that raised its demand hence second scramble. About 16 Acts were enacted annually since 1990 to fulfil the demand that caused the rise of the question whose state. Both Tanzania and Mozambique inherited colonial systems of natural resource management and ownership which continue to inform the current practice. The state apparatuses are the agents of accumulation. The situation will be tense in future if not addressed now.
\end{abstract}

Keywords: Land, Resource, Conflicts, Accumulation, Tanzania

\section{Introduction}

Tanzania has abundant natural resources both bio and physical resources which are a unique heritage. Tanzania has a rich diverse spectrum of fauna and flora including a wide variety of endemic species (URT, 1998). Tanzania is recognized in mining sector for its highly prospective geology of which some have yet to be established (URT, 1997). Gas, gold, tanzanite, coal and iron deposits are approved to be in abundance not only within Africa but at global comparison. The management and extraction of the resources have caused a series of conflicts in different forms over space and time. For instance, there has been conflict between artisan miners versus investors in Bulyahulu over right of occupancy and right to mine, villagers versus large scale miners in Nyamongo over minerals. Others are conflicts between farmers and pastoralist in Kilosa over land resources, Residents of Mtwara against the state over gas extraction and Israel investors versus residents in Ruvuma region over land resource.

Africa witnesses a new and massive land grabbing scramble. The justification for land grabbing in one hand is supposedly climate change which threatens the entire world (Madoffe et al., 2009). It is claimed there are enormous areas of unused land. If this is the case then why conflicts over land? Principally, any resource that has money value is scarce. If land is a resource how then is in abundance? There are about four million peasant families in Tanzania whose principal livelihood is obtained in small scale farming and pastoralism (Magimbi et al., 2010). These families have not settled in harmony. Conflicts have been experienced now and then. The conflicts may be between producers, and or producers and the state. In case of producers it may be pastoralists and farmers on one hand, and pastoralists and

\footnotetext{
${ }^{1}$ The paper was first presented on the Fourth International Conference on State, Natural Resources and Conflicts: Actors and Dynamics, August 2014, Maputo- Mozambique
} 
farmers against investors on the other hand.

The world economic situation has added pressure to exploit natural resources to the fullest extent possible to maximize exports (Wisner et al., 2005). After independence, foreign direct investment has been an alternative and has increased tremendously. Tanzania to date has about 11 Billion USD value of direct investment especially in energy and mining sectors (URT, 2014). If the capital is sent to foreign countries, it is done not because there is no absolutely labour force for it at home but for higher profit in the foreign country (Nabudere, 1979).

The nature and role of the state has changed because of globalisation challenges in terms of structures and actors such as transnational elites, Multinational Corporation and technological transformation (Jalata, 2002). The main role of the state to date is to balance competing social forces. Political Independence does not mean to have control over economic decisions and national economy (Rweyemamu, 1978). Institutional framework erected by Britain during colonial period ensured economic dependency. External preferences are the priority of the state. Sovereignty primarily means the state is autonomous and independent. (Rourke, 2004). This implies that the state sovereignty is a myth that does not exist. The contradictory relationship between the African periphery and imperialism constitutes the national question, and at the heart of this relationship lies the crisis of over accumulation which characterises capitalist economy (Magimbi et al., 2010).

\subsection{Conceptual Framework}

\subsubsection{Accumulation and Resource Based Conflicts}

The paper argues that resource based conflicts are results of historical and contemporary processes of accumulation. Accumulation is a historical process of separating independent commodity producers from the means of production (Shivji, 2009). It is a fundamental condition for capitalist production (Harvey, 2006). All accumulation outside capitalist mode of production is considered primitive accumulation. Primitive accumulation as the base of capitalism plays two roles. Firstly, the immediate aim of primitive accumulation was to acquire capital which also happens in Tanzania through land speculation and grabbing. Secondly, to create conditions for capitalist accumulation, for example; separating producers from means of production hence supply of exploited labour and market. Even though primitive accumulation of capital was able to separate producers from means of production at the core, in periphery capitalism accumulation takes place without necessary separation of producers from means of production. This is done through disarticulation of the economies.

Primitive accumulation of capital does not stop, rather continues as accumulation by dispossession as described by Harvey (Harvey, 2005; Shivji, 2009). The accumulation by dispossession is observed in privatization and commodification of everything. Cumulative effect of accumulation over a long time blasts in form of conflicts within the society. Since colonial period to date, the state plays an important role for capitalism accumulation to take place. Colonial state controlled every aspect of economy access/or ownership of land, what to produce, how to produce and who to produce (Kamata and Haulle, 2012). The situation has continued in the same way in form of African managers because African states were the products of colonial states. This is the assumption that the state is not African for Africans. The existing states play the middleman role for the metropolitan states. Colonial masters handled over a state to Africans of their choice in the form of neo-colonialism.

Post-colonial states did not transform disarticulated economies, instead turned to be instruments of accumulation (Shivji, 2009). Many economic activities were still controlled by the state. Political powers determined everything. Issues of land tenure; what to produce, how to produce, who to produce for which market continued to follow the colonial system.

During neo -liberalism that started to be experienced in early 1980s and intensified in 1990s, accumulation by dispossession continues to be intensified and multiplied. It resulted in vibrant loss of popular means achieved through various struggles after independence. Violence and dispossession are done in the name of public interest, good governance and rule of law. Neo -liberalism informs the policies, laws and regulations.

The current economic situation shows that there is so limited effort to develop majority of Tanzanians who depend much on agriculture. Agricultural sector grows at $4.3 \%$ annually instead of $10 \%$ as planned in MKUKUTA. While fishing declined from 2.9 to $2.2 \%$ in 2012-2013 (URT, 2014), the national economy grows at 7\%. Sectors that are controlled by few lead the economy communication (22.8\%). Most of these leading sectors are not production sectors. On the other hand, the national debt grows geometrically. It is now more than Tshs. 27 Trillion This has tripled in the last nine years and in fact about 8 Trillion were added over the last financial year. This situation causes problems to majority of Tanzanians who produces what they don't consume and consumes what they do not produce. However, the government assures the public the debt is very small and bearable (URT, 2014). The dependency is strengthened by this nature of the economy and sector development.

\section{Methodology}

The study was carried out focusing on two areas which are Ngorongoro and Kilombero districts in Tanzania. 
Ngorongoro has been taken because it is among of good cases that deal with land resource conflicts in relation to wildlife conservation and human livelihood nexus. Ngorongoro district is located in Arusha region Northern Tanzania. It has Serengeti National Park, Loliondo Game Controlled Area (LGCA) and Ngorongoro Conservation Area (NCA) which is the World heritage site and the Biosphere Reserve (Haulle, 2014). NCA is now among the seven wonders of Africa. Kilombero district was selected and involved in the study because it is a very fertile valley in the Rufiji basin. It is highly involved in agriculture. Large scale investors interact with small farmers. The district is located in Morogoro region Eastern Tanzania.

Primary data were obtained through in depth interviews and Focus Group Discussion (FGDs). The techniques had power to provide inner understanding of the matter in the community. The techniques were employed to capture information relating to land resource availability, access and control over time. Furthermore issues relating to change of livelihood pattern and land resource conflicts were assessed. These were employed to both individuals and leaders related to the issues in the districts.

Documentary search was employed to obtain secondary data that supplemented the primary data collected. Historical development of land tenure system and land use was clearly captured by Documentary search. Further, the existing situation was also reviewed through mass media.

\section{Research Findings and Discussions}

\subsection{Land Tenure Trend in Tanzania}

On November $26^{\text {th }}, 1895$ the German instigated that all the land in German East Africa was under the Crown (Maghimbi et al., 2010). The significant change of land tenure in Tanzania can be traced back to 1923 when the British declared all land in colonial Tanganyika, occupied and unoccupied to be a public land (URT, 1994a; URT, 1999). This was the massive grab of land from the people by the state. However, the freeholds that were issued by the Germans like those of Unyarubanja were preserved to post independence. This helped the colonial state to alienate any piece of land for whatever reasons. The tenure helped the establishment of the present national parks and conservation areas like Serengeti National Park (1951) and Ngorongoro Conservation Area (1959) (Shivji and Kapinga, 1998; URT, 1994a; URT, 1994b).

The system provided for granted rights and deemed rights as per customary laws. Independent Tanzania declared all land to be owned by people under the trustee of the president (URT. 1999; URT, 1999a). All freeholds were abolished and changed to leaseholds. Nyarubanja system was abolished officially in 1968 including all feudalistic characteristics. In 1969 all leaseholds were converted into right of occupancy (Kamata and Haulle, 2012). There were efforts to form nation building project. Many independent African states embarked on the project. . This means that the land tenure in this system is that those who "own" land do not really own it instead they only occupy and use it as tenants. They can continue using as long as the ultimate owner does not need to use it.

The land tenure system helped Tanzania during Arusha declaration to nationalise private property in the name of public interest. This was possible through exercising power vested under president. A lot of public institutions were established after the Arusha declaration in 1967. It was from this privilege the state companies like National food company (NAFCO), National Ranch Company (NARCO), Tanzania National Parks (TANAPA) and so many more got land from people in the name of public interest (Shivji, 1998). This went hand in hand with villagelisation. People were forced to leave their places to establish ujamaa villages "Sogeza" that dominated in 1974.

During liberalisation, the policy that was championed by Capitalist states and World Bank, People were allowed to go back to their land before villagelisation. The decision caused confusion and insecurity (Kamata and Haulle, 2012). Conflict of compensation to people who were relocated to the plot by the state (by force as well as previous customary rights) started to rise. In economic liberalisation, issues of double allocation were dominant.

Through the commission of land inquiry in 1994, there were three issues noted. Firstly, pervasive insecurity of tenure because of limited transparency and participation of people. Secondly, radical title by government officials, thirdly, was overlapping institutional structures over land allocation and administration and dispute settlement (URT, 1994; URT, 1994a). The commission recommended reform of land tenure. Land should be owned by Village Assembly and National Land Commission. There should be modification of customary titles for security of tenure to smallholders ceiling ownership on village land, and land to be a constitutional category.

According to Kamata and Haulle (2012), it should be noted that, during the process of inquiry, the government rushed and drafted land policy that was officially issued in 1995. The policy mainly responded to liberal economy concepts of land value, land market in relation to existing economic system "Free market". The policy emphasized on what was set in 1923. All land in Tanzania is public and vested in the president as Trustee. It added some aspects that land has value; fair compensation will be paid; and rights of land to people will be taken under law consideration. The justification for 
the policy was to create "enabling environment for attracting foreign investment". This was also followed by land Act and Village land Act no 4 and 5 of 1999 respectively.

The right of occupancy follows the following principles: firstly, the security of tenure depended on use; secondly, whenever the acquisition was necessary, payment of compensation would be due, but only for the exhaustible improvements and not for bare land (Shivji, 2006). Thirdly, the right of the state to revoke the granted right of occupancy, and fourthly, customary right of occupancy is deemed and has no term limit. Generally, since 1923 to date, these principles have been the basis for land tenure system in Tanzania (Shivji and Kapinga, 1998).

\subsection{Ngorongoro District}

Ngorongoro District is primarily inhabited by pastoralists and agro- pastoralists (URT, 2006). The district faces a lot of conflicts for many years. The Maasai keep their cattle through transhumance practice. They move up and down within the Maasai Bloc or Maasai steppe (Haulle, 2014).

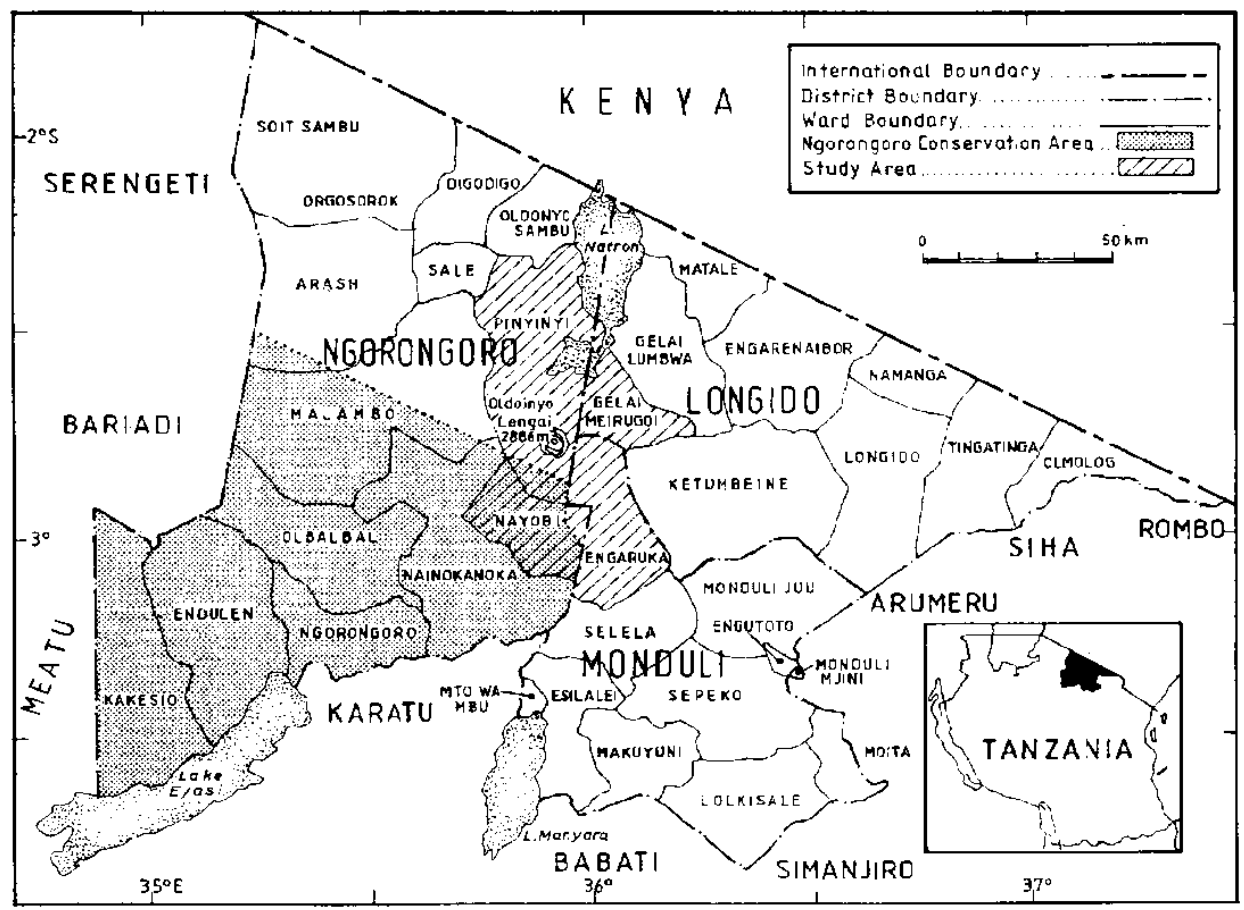

Figure 1. Ngorongoro Conservation Area and Loliondo Game Controlled Area

Source: Haulle, 2014

In this situation, it is clear that it is difficult to establish the principle of occupancy that insists on the security of tenure. Land tenure here depends on the use. Furthermore, where the acquisition is necessary, compensation will be done to the improvement done on the land (Kamata and Haulle, 2012). The conflicts in this district are related to conservation and tourism versus other land use demands. In this situation, there are two major cases relating to conservation in the district. The first is that which relates to Ngorongoro Conservation Area (NCA) and Ngorongoro Conservation Area Authority (NCAA). The second is that which relates to Loliondo Game Controlled Area (LGCA).

\subsubsection{Ngorongoro Conservation Area}

The existing problems in NCA can be traced back to 1923 when the Land Ordinance provided power to the Governor over land. In 1951 through exercising power vested to Governor of Tanganyika, there was establishment of Serengeti National Park. In setting the Park, the Maasai who were using Serengeti National Park as their pasture and residential area were denied their use (Shivji, 1998). The Colonial state set an agreement with Laigwanans (Maasai elders) to alienate the land from the pastoral society for conservation. In this agreement, the Maasai were to settle in the current NCA. Moreover, in 1959 the establishment of NCAA maintained the rights of the Maasai and Pastoralists in the area although there were some restrictions on how they could live and move within NCA. The study found out that the residents had to have special identity that proofs their residence within Ngorongoro district. Their settlement and livelihood pattern had to be regulated over space and time. 


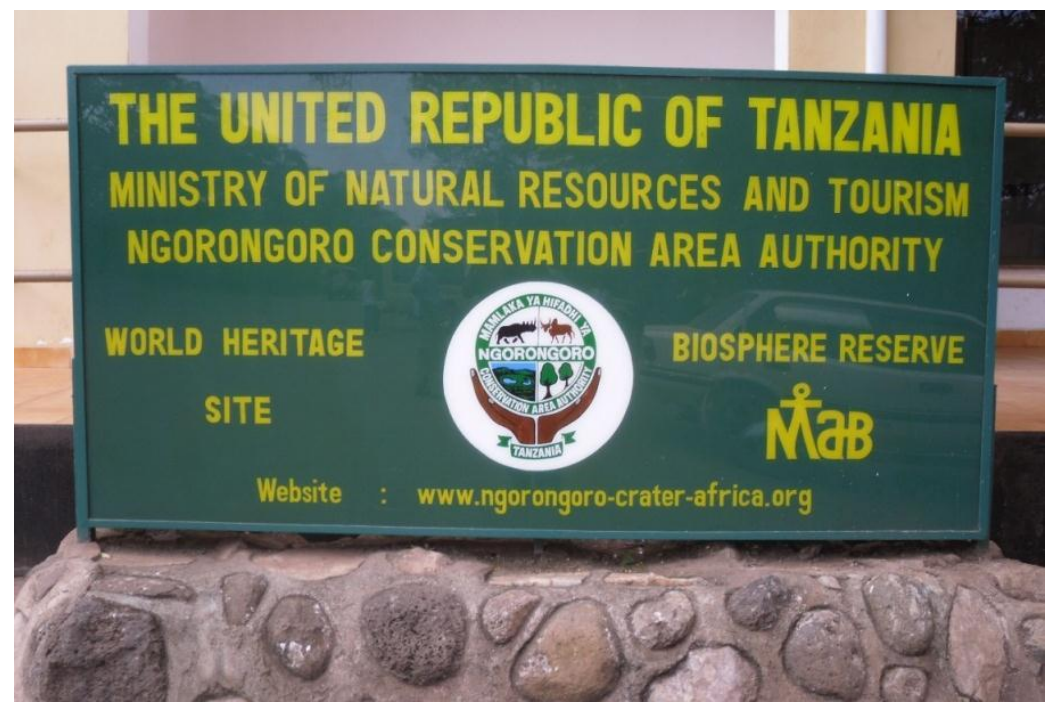

Figure 2. The signpost showing the status of the NCA

Source: Haulle, 2014

This is clearly observed in its establishment that Maasai were considered to live harmonious with Nature. In this case, Maasai settlement and their livelihood would not jeopardise wild life conservation in NCA. It should also be noted that Maasai were blended to be nomadic and pure pastoralists without any form of cultivation. However, studies show that the Maasai are practising sedentary life and subsistence cultivation of the so called vibustani (Shivji 1998; Haulle, 2014).

The Ngorongoro Conservation Area Authority Act underwent a lot of changes to the extent of prohibiting any form of cultivation. Furthermore, other livelihood options and individual development initiatives were moderated in preference to wildlife conservation and management (URT, 2002a). Such activities include construction of brick wall houses and cutting poles for construction. Movement of people within NCA during the right as per Penal Code (CAP 16) are prohibited. All kinds of development in NCA had to get a consent of NCAA.

In 1990, the third President of the United Republic of Tanzania tried to resolve the land use conflict. He allowed the Maasai and all residents within NCA to continue to cultivate some vibustani for their survival. It should be noted that, with such power rested on President of land, he had such powers. However, the Act remained unchanged. This is the reason why after his term, any sort of farming was prohibited again. One elder from Nayobi "Village within NCA explained that:

"When we cried to President Mkapa, we were allowed to continue to cultivate. Later when he got out of office, we were prohibited again promising that the Authority will provide food for us that we have never seen”.

To date with the pressure from UNESCO which has granted NCA the World Heritage site and Biosphere Reserve, and the recent declaration of NCA as one of the Seven Wonder of the Africa, prioritise the conservation of wildlife in the expense of human kind. When UNESCO threatened to withdraw the status due to human activities in NCA, the government decided to prohibit any cultivation and other livelihood options besides pastoralist and trade.

Moreover, in order to maintain the status, it was alarmed that there is rapid population increase in NCA to the extent that it threatens wildlife, and therefore, control of livestock and people is to be paramount. NCA five year-plan insists on control of the growing population in NCA (URT, 2006). It was also noted that more than 200 households were relocated from NCA to Oldoinyo Sambu. This relocation was forcefully brutal. It was also noted that the relocation plan is continuous.

\subsubsection{Loliondo Game Controlled Area}

This area is located between NCA and Serengeti National Park within Ngorongoro District. It is a wildlife corridor. LGCA like NCA and Serengeti which are known as Maasai Steppe or Maasai block were habited by Maasai. LGCA was contracted to three companies; Thomson Safaris, Andrew and Ortles Business Company (OBC). The companies deal with commercial hunting and photographic tourism. It is clear that there was no negotiation upon their imposition in the area while all villages are registered under the village act of 1975 and protected by village land Act No. 5 of 1999 (URT, 2002b; URT, 2002c; URT, 2002d).

Thomson Safari quarrelled with the villagers when it was noted that the area of Thomson Safari was increasing from 
$4000 \mathrm{~km}^{2}$ without notice year after year. Furthermore, people were prohibited to use water points for their livestock and domestic purposes. This caused misunderstanding in 2009 through 2010.

Serious conflicts are experienced between the villagers, Police force particularly Field Force Unit (FFU). OBC was operating in an area since 1992. The people who were living in this area over years were alleged to trespass and deplete the environment. However, it should be noted here that, with the establishment of Wildlife Conservation Act no 5 of 2009, Game Controlled Area were not supposed to support human sedentary life. This implies that the Act was established to suit the interest of investors. In fulfilling such requirements, the eviction was done in the area with effect from 4th July, 2009. It was reported that about eight (8) women were raped and fifty thousand $(50,000)$ cattle were displaced. Further, about two hundred (200) Maasai households lost their bomas while 3, 000 were Internally Displaced People (IDPs).

There was a clear link between government and investors. The government entered into a contract with community members on behalf of $\mathrm{OBC}$ to resolve the conflict though there was no chance of negotiation on the terms for dispute to people. People only had to comply with terms and conditions. Furthermore, FFU Troops were hosted within OBC camps (Haulle, 2014). Moreover, the OBC area was protected by National Police Force. Any person who wanted to observe the $\mathrm{OBC}$, even having photographs relating to $\mathrm{OBC}$, was victimised.

The company is further questioned on its legitimacy whether it is a state agency or like any other registered private company. . In previous years, there were observed vehicles without registration numbers and some with UAE registration. The area had a very big air strip that allowed landing and take-off of large planes. The local people were not allowed to enter the OBC area, and therefore, nobody could check what was going on inside. The shocking story was the mobile phone coverage in the area was different. Most of the visitors in the area could receive this message:

"Dear guest, welcome to UAE. Enjoy the best network coverage and other unmatched services only with Etisalat. Please..... have a pleasant stay in the UAE"

This message is not observed to date. It might have been changed after a lot of queries from citizens. However, the question whose state whose resource is still unanswered.

It was noted that, after the conflicts in 2009, people were allowed to settle in the disputed environment. In 2013, the government issued a press release that focused on resolving the conflicts existed between Serengeti National Park, NCA and LGCA. The government declared to release about 2,500 km2 which was part of LGCA to be a village land to eight villages in order to remain with $1,500 \mathrm{~km} 2$. As opposed to this statement, the community in Ngorongoro revealed that the government did not release land instead grabbed about $1,500 \mathrm{~km}^{2}$ of the little land remained for their survival in the name of conservation. The proposed corridor will reduce $40 \%$ of the remaining land in Ngorongoro.

"Many people's livelihood totally depends on livestock. We will die if we don't have land to graze; this will affect almost the whole of Ngorongoro District. We will fight against until the last person is gone......."

"We were relocated from Serengeti. It is astonishing for the government to come up with the idea of chopping part of the land and give it to investors. The idea of further relocation is unacceptable. The land we are claiming is ours....." One of the Ward Councillors strongly lamented.

\subsection{Kilombero District}

Land resource in Kilombero district is mainly used for agriculture. However, mining and conservation like a newly established Udzungwa National Park is taking portion of the district. The area has about three main investors who are Ilovo Company, Kilombero Plantation Ltd (KPL) and Kilimo cha Yesu (KCY). Ilovo Company is South African cultivating cane and produce sugar. It has 25,000 ha obtained from SUDECO after privatisation. So, Ilovo inherited such land that was obtained in 1963 from the people by the state. After a while, it was noted that, about 1976 ha were invaded by Selous Game Reserve, Msolwa station and Nyange Village. The settlement in this area was well established with social services. About 2000 families were to be relocated. In order to compensate the loss, the government showed the land in River Lwipa. However, Ilovo demanded 6000 ha instead of 1976 ha. On top of that, Ilovo was not willing to compensate whoever invested in the land granted. This plot has not yet been put into production. Ilovo want to establish another factory in Lwipa valley.

KPL acquired 14,556 ha of land through RUBADA, even the title was complicated in the process of issuing. KPL deals will rice production. However, it will involve itself in Hydro Electric Power (HEP) production and Real Estate service. About 3000 ha are under well mechanised farming. It is located in Mngeta and Mkangawalo villages. There was relocation of about 60 families from the area with compensation. However, the use of aerial spray of pesticides and fertilizers affected about 700 people in the vicinity of the KPL farm. Besides such effects, the Company did not admit liability. The investigation team that was instituted by Tanzania Pest Research Institute (TPRI) was not put in public to date. 
Kilimo cha Yesu (KCY) is a Swiss Company that deals with maize and rice production in Mpanga Ward in Mlimba division. They lease tractors to villages and hire cheap labour in their plantation. They also lease farms for others to cultivate. $\mathrm{KCY}$ is still expanding its production. What can be observed is that, this company is just speculating the land.

General Observation in the Kilombero is that all those three companies employed human labour force which was lowly paid.

"Provided that all the companies have mechanised production, all companies employ labours in order to provide employment and income to people. Ilovo is also employing out growers........It is true that they are lowly paid" Land Officer.

The investors in this area were supported by RUBADA to acquire land with exception of Ilovo. Ilovo obtained the land that was taken from people in 1960s supported by Public Sector Reform Commission (PSRC) which is also a state company. There was also relocation of people with change of production to meet the market. People had to leave producing other crops in order to produce sugar-cane.

\subsubsection{Namawala Village}

Although the researchers were prohibited to interview people in this village, it was noted that people were protesting against providing land to investors. People did not want to give out land for any investment, and they were not willing to cultivate sugarcane in any form (as out growers or plantation). The district officials interrupted the village decision in favour of RUBADA, SUDECO and investors. People demanded negotiation with the investor not with the middleman. This led to suppress meetings relating to land issues and imprisonment of village officials to the extent that even land use planning is not successful to date.

"We know SUDECO deals with sugar management but not farming, how come today SUDECO cultivates sugarcane? What is behind this search of own land? We don't need any intruder here even those who wrote you a letter (Research Clearance) know it very well, that is why they called Village Officer to their Office so as not to see such confrontation"..... One man was speaking to the research team.

"In short what you want is not possible here! Nobody will be interviewed". Another responded to the team.

This happened when there was high tension of land grab in this area. SUDECO and RUBADA are both government agencies. Both of them are not using land either. For whose interest are they working?

\subsection{The Impact of the Current Land Resource Management}

The impact of accumulation of land through dispossessing the community by the state has caused a number of problems. Such problems included settlement in fragile environment like the vicinity of Oldoinyo Lengai which is an active volcano adjacent to the boundary of NCA.

Due to alienation of resources from people, conflicts have emerged over little resources that are needed to be used by many. Conflict over pastureland and settlement among the pastoral and agro pastoral societies have been reported now and then in the area. (Shivji, 1998; Mwami, 2009 and Haulle, 2014). Similarly, the case of Kilosa killing could not happen if there were not big chunks of land used for tourism and large scale investors leaving pastoralists and farmers landless.

Decline of standard of living like literacy level, health and economic condition of the people has been one of the main adverse impact. People who settle in NCA are impoverished day after day while NCAA collects a lot of revenue through tourism, and subsidies from being a World heritage site and biosphere reserve, and recently being among the Seven Wonders of the Africa. Those people who live in the protected environments are to adhere to certain rules that govern the area.

The impacts of such conflicts have caused a serious trauma in the area. For instance, researchers can now fail to get support and cooperation just because they are considered to be part of FFU and State machinery which are not for people (Haulle, 2014). This was evidenced in Olerieu Magaiduru and Nayobi villages where researchers could not get required informants fearing being the agents of eviction. Similarly, the case of Namawala showed the same scenario that researchers were considered agents of dispossession.

Most of the Maasai in this area have migrated to other parts where then conflicts between farmers and pastoralists sparked. Eastern and Southern Tanzania experience such conflicts over resources. Such conflicts can be experienced in coast region, Lindi and Mbeya where they were not experienced earlier.

Conservation strategies have lost a lot of lives in Tanzania. The good example is the anti-poaching operation in Tanzania. This showed several people lost their lives in 2013 that caused the resignation of the Minister responsible for wildlife management and tourism. 


\subsection{Different Forms of Land Alienation}

The state plays a role as agent of land alienation by encouraging investors on land, convincing people to accept land speculators and sometimes forces people to accept investors. A state enters contracts on behalf of foreigners and protects them (Haulle, 2014). Land alienation from producers is carried out through application of force and negotiation. Negotiation can be attained through a series of trickery on benefits provided by investors. In the process of negotiation, the government may directly stand for investors, and sometimes, amend the laws to suit the purpose. For example; there were dubious and bad contracts signed between the Government and Investors (LHRC, 2010). People wonder how the government justify continuing to allocate budget to private Investments which is used to siphon national resources into private pockets. Such projects include Buzwagi Contract, IPTL, Richmond and TRL scandals. It was noted that, since introduction of liberalisation, an average of sixteen (16) acts are enacted per annum in the name of creating enabling environment for investments.

Land is alienated to foreign investors by state through different agents. Tanzania Investment Centre (TIC) is among the centres established to earmark all parts that seem fit for investment and attract investors to come and grab land for different purposes. The unit deals all over the country, and in fact, each investor has to go through this unit. Rufiji Basin Development (RUBADA) was established in 1976 for the purpose of developing Rufiji Basin in terms of agriculture and Hydro Electric Power. However, to date the organ is soliciting land from people and inviting investors to the land within Rufiji Basin. Individual political leaders and elites have played a significant role in land acquisition. They have pursued peasants to offer land in order to attain other benefits which in many cases have never been realised. This is done for the purpose of attracting foreign investment that in turn will lead to economic growth.

On the other hand, when negotiation fails force is used in the name of public interest. (Mwami and Kamata, 2011). This can clearly be seen in Ngorongoro area, Nyamuma in Serengeti and Ihefu in Mbeya. It was also employed in other privatisation and investment sectors. For instance; Net Group Solution management entered the office of TANESCO under full control of FFU. The Israel Company that deals with coffee cultivation in Ruvuma region southern Tanzania near the boundary with Mozambique is accused to beat and harass people who do not wish to sell their land to investors with the support of the state machinery. About 1,018,038,734 ha of land have been requested by different foreign companies through these agents only for biofuel production (HakiArdhi, 2013). This does not include those who request land through specific village councils.

\section{Conclusions and Recommendations}

The way land resource is managed in Tanzania has never changed since colonial era. The land tenure has never changed its strict sense instead changing the wording. The land tenure that exists to date is insecure to the majority Tanzanians due to inherent characteristics of colonialism. People have been alienated their land in the name of public interests and turned to be wonderers in their own country. The little compensation instituted is useless and in some cases is not adhered to as the case of Ilovo Company. No any stable legal system that controls the investors. It appears that there is no any economic partner that has found land tenure and security to produce adverse impacts to people. Through land, people earn living, but now the gap between the rich and the poor is greater than before. He who pays the piper chooses the tune, tells us whose state it is and whose resource it is. This situation is recurring almost all over Africa and Mozambique is not exceptional. This is because the inherent colonial characteristics prevail to date. The second rush for biofuel production and gas and oil exploration and other agriculture activities that Tanzania experiences are also facing Mozambique. In other cases some villagers have limited awareness on the power of the village council on the land management. Those people who were aware caused were able to resist loss of their land either by force or diplomacy.

It is recommended here that, unless the community is given its power over its resources, sustainable development will not be attained. The existing conflicts will double if land management is not properly managed. There is need to restructure the land tenure in Tanzania in order to control the abuse of power over land resources. There is need for increasing community awareness on legal and social processes on land.

\section{References}

HakiArdhi. (2013). Biofuels in Tanzania: Small Scale Producers and Sustainable Environmental Management, HakiArdhi, Dar es Salaam

Harvey, D (2006). Spaces of Global Capitalism: Towards a Theory of Uneven Geographical Development, VERSOLondon.

Harvey, D. (2005). A Brief, History of Neo-Liberation. Oxford University Press, London.

Haulle, E. (2014). Assessment of Communities `Coping mechanisms to Geodisaster Risks in the Vicinity of Oldoinyo Lengai in Northern Tanzania, PhD Thesis, University of Dar es Salaam 
Jalata, A. (2002). Fighting Against the Injustice of the State and Globalisation. Comparing the Conflicts in East Africa, IDRC, Nairobi

Kamata, N., \& Haulle, E. (2012). Land, Ethnicity, Conflicts in Tanzania Land, Ethnicity, Conflicts in East Africa, IDRC, Nairobi.

LHRC (2010). Bunge Performance Assessment 2005-2010, Dar es Salaam.

Maddofe, S., Maliendo, S., Maganga, F., Mtalo, E., Midtgaard, F., \& Bryceson, I. (2009). "Biofuels and NeoColonialism" in Chemi chemi, Mwalimu Nyerere Professorial Chair in Pan- African Studies.

Maghimbi, S, Likina, R. B., \& Senga, M. A. (2010). The Agrarian Question in Tanzania. A state of the Art Paper; Mwalimu Julius Nyerere Professorial Chair in Pan - African Studies University of Dar-es-Salaam.

Mwami, A., \& Kamata, N. (2011). "Land Grabbing in a Post Investment Period and Popular Reactions in Rufiji River Basis" Occasional Paper, 3.

Nabudere, D. W. (1979). Essays on the Theory and Practice of Imperialism, TPH, Dar es- Salaam

Rourke, J. (2004). Taking sides: Clashing views on Controversial issues in World Politics, $11^{\text {th }}$ Edition. The MC Graw HILL Companies.

Rweyemamu, J. (1976). Underdevelopment and Industrialisation in Tanzania; A study of Perverse Capitalist Industrial Development, Oxford University Press, London.

Shiviji, I. G., \& Ally, B. (2011). Insha za Mapambano ya wanyonge, Taasisis ya Taaluma za Kiswahili, Dar es Salaam.

Shivji, I. G. (1998). Not yet Democracy: Reforming Land Tenure in Tanzania, HAKIARDHI, Dar es Salaam

Shivji, I. G. (2006). Lawyers in Neoliberalism: Authority's Professional Supplicants or Society's Amateurish Conscience, Veladictory on the occasion of formal retirement from the University of Dar es Salaam. Dar es Salaam: Faculty of Law, University of Dar es Salaam

Shivji, I. G. (2009). Accumulation in an African Periphery: A Theoretical Framework, Mkuki na Nyota Publishers/African Institute for Agrarian Studies, Dar es Salaam/ Harare

Shivji, I. G., \& Kapinga, W. B. (1998). Maasai Rights in Ngorongoro, Tanzania, HAKIARDHI, Dar es Salaam

United Republic of Tanzania (URT), (1994a), Report of the Presidential Commission of Inquiry of Land Matters, I; Land Policy and Land Tenure Structure, the Scandinavian Institute of African Studies, Uppsala

URT. (1994b). Report of the Presidential Commission of Inquiry of Land Matters, Volume II; Selected Land Disputes and Recommendations, the Scandinavian Institute of African Studies, Uppsala

URT. (1997b). National Land Policy. Dar es Salaam: The Ministry of Lands and Human Settlements

URT. (1998).The Wildlife Policy of Tanzania, Ministry of Natural Resource and Tourism, Dar es Salaam

URT. (2002a). Ngorongoro Conservation Area Ordinance Cap 413, the Parliament of United Republic of Tanzania, Dar es Salaam

URT. (2002b). Local Government District Authority Act of 1982 CAP 287, the Parliament of United Republic of Tanzania, Dar es Salaam

URT. (2002d). Village Land Act No 5, the Parliament of United Republic of Tanzania, Dar es Salaam

URT. (2006). Ngorongoro Conservation Area: General Management Plan 2006-2016, Ministry of Natural Resources and Tourism, Dar es Salaam

URT. (2009). Wildlife Conservation Act no 5 of 2009 the Parliament of United Republic of Tanzania, Dar es Salaam

URT. (2014). Hotuba ya Waziri wa fedha Mh. Saada(Mb) Akiwasilisha Bungeni Makadirio ya Mapato na, Matumizi ya Fedha kwa Mwaka 2014/15", Wizara ya Fedha, Dar es Salaam

URT. (2014a). Hali ya Uchumi wa Taifa katika Mwaka 2013, Ofisi ya Raisi Sera Mipango na Uchumi, Dar es Salaam

URT.(1997). The Mineral Policy of Tanzania, Ministry of Natural Resource and Tourism, Dar es Salaam

URT.(2002c). Land Act No 4, the Parliament of United Republic of Tanzania, Dar es Salaam

Wisner, B., Blaikie, P., Cannon, T., \& Davis, I. (2005). At Risk: Natural Hazards, People's Vulnerability and Disasters, Rutledge, London.

\section{(cc) EY}

This work is licensed under a Creative Commons Attribution 3.0 License. 